\title{
STUDIES ON THE MOLLUSCAN FAECES (II)
}

$\operatorname{AUTHOR}(\mathrm{S})$ :

Arakawa, Kohman Y.

\section{CITATION:}

Arakawa, Kohman Y.. STUDIES ON THE MOLLUSCAN FAECES (II).

PUBLICATIONS OF THE SETO MARINE BIOLOGICAL LABORATORY 1965, 13(1): $1-21$

ISSUE DATE:

1965-06-30

URL:

http://hdl.handle.net/2433/175396

RIGHT: 


\title{
STUDIES ON THE MOLLUSCAN FAECES (II)
}

\author{
Kohman Y. ARAKAWA \\ Hiroshima Fisheries Experimental Station, Kusatsu-minami-cho, \\ Hiroshima, Japan
}

With Plates $I-V I$ and 5 Text-figures

The work recorded in this paper is a continuation of the study on the molluscan faecal pellets, which has already been presented partly in a preliminary communication (ARAKAWA, 1962) and an initial paper of this series (Arakawa, '63). In this paper are included the descriptions of the pellets of fourty-four more molluscan species which were collected at several locations in the Seto Inland Sea and the vicinities in these four years.

Before passing to the descriptions, I wish to express my cordial thanks to the following gentlemen who offered me facilities or help in carring out the present work: Dr. Toshijiro Kawamura' (Hiroshima University), Dr. Ryozo Yagiu (Hiroshima Univ.) Dr. Takasi Torioka (Seto Marine Biological Laboratory), Dr. Yoshimitsu Ogasawara (Naikai Regional Fisheries Research Lab.), Dr. Huzio Utinomi (Seto Mar. Biol. Lab.), Mr. Nobuo Matsunaga (Isumi Senior High School), Dr. Katura Oyama (Geological Survey), Dr. Iwao TAKI (Hiroshima Univ.), Dr. Kikutaro Baba (Osaka Gakugei Univ.), Dr. Shigeru Ota (National Pearl Research Lab.), Prof. Jiro Sénô (Tokyo Univ. of Fisheries) and Mr. Masa-aki Hamai (Hiroshima Fish. Exp. Sta:).

\section{MATERIAL}

The scientific names, localities and types of faeces of respective species treated in this work are listed below.

\begin{tabular}{|c|c|c|c|}
\hline & Species & Locality** & Type of faeces* \\
\hline \multicolumn{4}{|l|}{ POLYPLACOPHORA } \\
\hline Ischnochitonidae & 1. Ischnochiton comptus & Shirahama & (S) Subovoid \\
\hline \multicolumn{4}{|c|}{ GASTROPODA } \\
\hline Haliotidae & 2. Nordotis discus & $"$ & (C) Columelliform \\
\hline Fissurellidae & 3. Montfortula pulchra & " & (S) Quasi-cylindric \\
\hline Patellidae & 4. Cellana nigrolineata & $"$ & (") Spiral \\
\hline \multirow[t]{3}{*}{ Acmaeidae } & 5. Notoacmea fusconigra & ” & $(") \quad "$ \\
\hline & schrenckii & Miyajima & (") \\
\hline & 7. Collisella heroldi & Miyajima & (") Orthocylindric \\
\hline Trochidae & 8. Trochus sacellum rota & Shirahama & (C) Quasi-columelliform \\
\hline
\end{tabular}

Publ. Seto Mar, Biol. Lab., XIII (1), 1-21, 1965. (Article 1) 


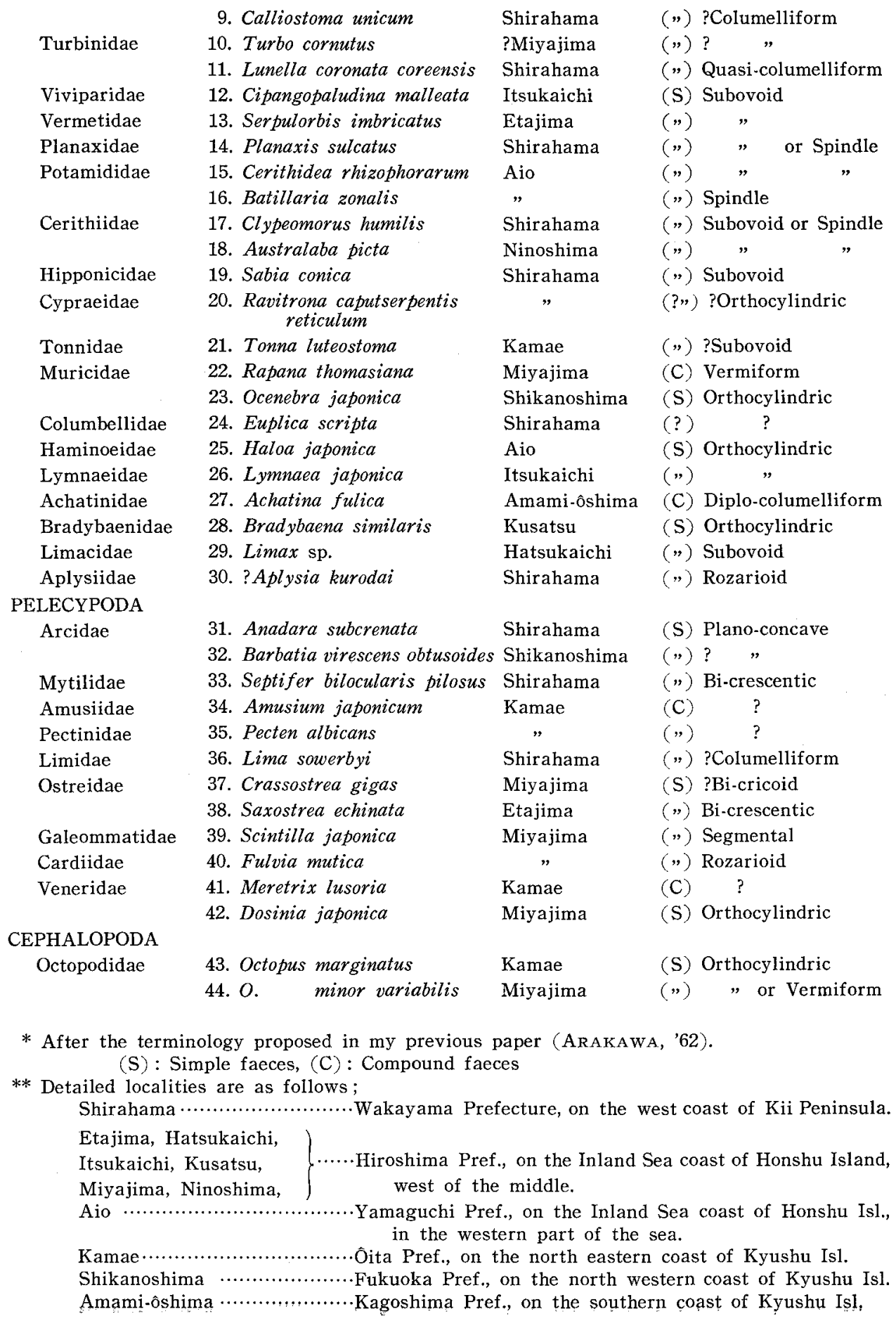




\section{DESCRIPTIONS}

1. Ischnochiton (Ischnochiton) comptus (GouLD, 1859)

Japanese name: Usu-hizara-gai

(P1. I, fig. 1)

Faeces are ovoid and shed occasionally united together in a chain. They are composed mostly of undigested fibrous materials which may present a cloth-like appearance partly on the surface. In color, they are grayish white and dotted with purplish black. The size of pellets varies greatly.

Measurement;-

Size of animal $(\mathrm{cm})$

2.1 in length (Spec. No. 120)

Diam. of pellet $(\mathrm{mm})$

0.64

0.87

0.97

Length of pellet $(\mathrm{mm})$

1.42

2.73

2.91

Length/diam.

2.20

3.13

3.00

2. Nordotis discus (REEVE, 1846)

Japanese name: Kuro-awabi

(Pl. I, figs. 2-3)

The pellets in this species are of the same type as those of Haliotis japonica in general appearance. They consist each of constituent faecal filaments loosely packed by mucus into an elongate rod with a rounded section. The rod is covered outside with a jelly-like membrane (or sheath) except for the mid-ventral line where the jelly membrane is cut off longitudinally. The rods are $0.64 \mathrm{~mm}$ in diameter including the sheath and the constituent filaments are $0.04 \mathrm{~mm}$ in diameter for an examined animal.

\section{Montfortula pulchra ADAMs, 1852}

\section{Japanese name: Suso-kake-gai}

(P1. I, fig. 4)

This species sheds faeces in rods with a rounded section. They are coarse in texture, rather soft in consistency and light whitish green in color, and are built of coarse fragmentary materials probably algal in origin. For an animal with a shell $0.9 \mathrm{~cm}$ long and $0.6 \mathrm{~cm}$ high, the diameter of pellets is $0.31 \mathrm{~mm}$, 


\section{Cellana nigrolineata (REEvE, 1854)}

\section{Japanese name: Ushi-no-tsume, Matsuba-gai}

(P1. I, fig. 5)

This species voids rod-shaped pellets marked with a single sinistral spiral groove. They are soft and homogeneous in consistency, light grayish yellow in color, and fairly coarse in texture of the surface. They are composed of fully-digested algal matters and some diatom tests (Skeletonema, Navicula etc.). For an animal with a shell $3.2 \mathrm{~cm}$ long, the diameter of faeces flactuates in the range $0.55 \mathrm{~mm}-0.60 \mathrm{~mm}$.

\section{Notoacmea fuscoviridis TERAMACHI, 1949 \\ Japanese name: Kusa-iro-ao-gai}

(Pl. I, fig. 6)

Faecal rods of this species are marked with a sinistral spiral groove. They are grayish brown in color, sometimes patched or striped with bands of darker hue. They consist of rather coarse algal fragments. The diameter of the rods shed by an animal with a shell $1.7 \mathrm{~cm}$ long, is $0.36 \mathrm{~mm}$ on an average.

\section{Notoacmea schrenckii (LiSCHKE, 1868)}

Japanese name: Ao-gai

The faecal rods are cylindrical and marked with a single sinistral spiral groove. They are coarse in texture, rather firm in consistency and usually dirty yellowish green in color. They are composed of rather coarse fragments of green and brown algae. For an examined animal, the diameter of rods is $0.37 \mathrm{~mm}$ on an average.

\section{Collisella (Conoidacmea) heroldi (DUNKER, 1861)}

Japanese name: Kogamo-gai

The voided rods are cylindrical in shape and with a smooth and unsculptured surface, and bowed slightly and evenly. They are formed almost of algal fragments containing some diatoms (Navicula, Corethron, Achnanthes etc.), with finer material in the axial and ventral part, whereas the coarser material in the peripheral and dorsal parts. They are yellowish brown in color, rather 
fine and homogeneous in texture. For an examined animal, the pellet-diameter is $0.20 \mathrm{~mm}$ on an average.

\section{Trochus sacellum rota DUNKER, 1860}

Japanese name: Uzu-ichimonji

(Pl. I, figs. 8-10)

The faeces are rather complicated in structure. They are rod-shaped and with two deep narrow ventral grooves, so that the cross-section is roughly elliptical, somewhat depressed dorso-ventrally and marked with two notches on the ventral side. The rods are composed of two kinds of materials : the coarse material in the axial part which is derived from the "stomach string" according to the terminology suggested by CARRIKER (1946) and the finer material, in the dorsal and peripheral parts and along the mid-ventral ridge, derived from the "liver string" which is arranged to form obscure and somewhat irregular undulations on the surface. The average diameter of the faeces voided by an animal with a shell $2.5 \mathrm{~cm}$ in height, is $0.65 \mathrm{~mm}$.

\section{Calliostoma (Tristichotrochus) unicum (DUNKER, 1860)}

\section{Japanese name: Ebisu-gai}

$$
\text { (P1. I, fig. 7) }
$$

The faecal pellets of this species are somewhat simpler than those of other trochids so far described. They are rod-shaped and without any prominent surface sculptures, and consist of thin thread-like constituent pellets compacted loosely by mucus. They are roughly circular in cross section, soft and frail in consistency and dirty yellowish green in color. The surface is not smooth and considerably rough in texture. The diameter of the pellets shed by an examined animal ranges from $0.55 \mathrm{~mm}$ to $0.64 \mathrm{~mm}$ and that of constituent pellets is $0.15 \mathrm{~mm}$ on an average.

10. Turbo (Batillus) cornutus SolANDER, 1786

\section{Japanese name: Sazae}

(P1. I, figs. 11-12)

This species gives off much complicated faeces. They are rod-shaped, consist of tightly packed thread-like constituent filaments, roughly circular in cross section and colored grayish white or sometimes variegated with lighter or darker hue. The pellets are composed mostly of algal matters 
and some indigested materials such as foraminiferal shells, broken pieces of calcareous algae and other skeletal matters. The diameter of faeces shed from an examined animal, is $2.74 \mathrm{~mm}$ and that of constituent filaments $0.11 \mathrm{~mm}$.

11. Lunella coronata coreensis (RÉCLUZ, 1853)

\section{Japanese name: Su-gai}

(Pl. II, figs. 13-15)

The faecal pellets of this species show a structure similar to that of the trochids. They assume roughly a cylindroid rod with two deep longitudinal ventral grooves. The dorso-median line is slightly depressed to form a shallow and wide longitudinal groove, and the dorso-lateral surface is marked with complicated but obscure undulations. The pellets are soft and fragile in consistency and light yellowish brown in color, and are formed of fully digested materials probably of an algal origin. The faeces voided from an animal with a shell $1.4 \mathrm{~cm}$ in height, is $0.75 \mathrm{~mm}$ in major diameter.

\section{Cipangopaludina malleata (REEvE, 1863)}

\section{Japanese name: Maru-tanishi}

(P1. II, fig. 16)

Even the faecal pellets shed by the same animal within a short time vary much in size and shape, although they are usually ovoid, brown in color and coarse in texture. The proportion of length to diameter fluctuates to a great extent as shown below :

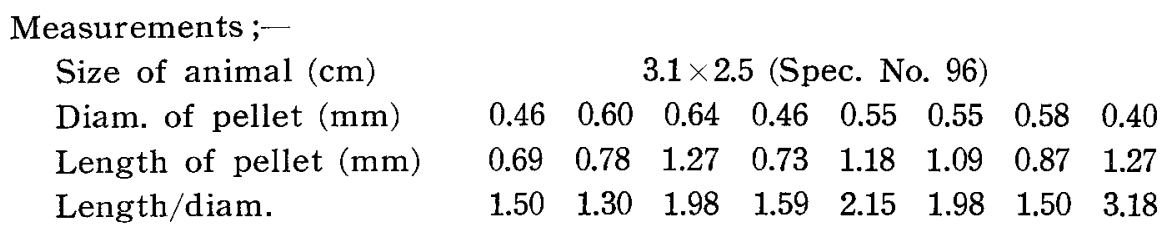

13. Serpulorbis imbricatus (DUNKER, 1860)

Japanese name: Ôhebi-gai

(Pl. II, fig. 17)

The pellets are usually ovoid, or ellipsoid, but are found sometimes united together in chains. The superficial consistency is fine, homogeneous and 
unsculptured. They are colored uniformly dark green and consist mostly of fine detritus including some diatom frustules and spicules. The average proportion of length to diameter of the pellets shed by an animal with a shell $1.0 \mathrm{~cm}$ in apertural diameter, is 1.79 .

Measurement ;--

Size of animal $(\mathrm{cm})$

Diam. of pellet $(\mathrm{mm})$

Length of pellet $(\mathrm{mm})$

Lengtn/diam.
1.0 in apertural diam. (Spec. No. 93)

$\begin{array}{llllllllllll}0.46 & 0.47 & 0.46 & 0.47 & 0.47 & 0.44 & 0.46 & 0.44 & 0.46 & 0.46 & 0.44 & 0.44\end{array}$

$\begin{array}{llllllllllll}0.84 & 0.84 & 0.91 & 0.86 & 0.93 & 0.67 & 0.76 & 0.82 & 0.69 & 0.82 & 0.82 & 0.82\end{array}$

$\begin{array}{llllllllllll}1.83 & 1.79 & 1.98 & 1.83 & 1.98 & 1.52 & 1.65 & 1.86 & 1.50 & 1.78 & 1.86 & 1.86\end{array}$

\section{Planaxis sulcatus (BORN, 1780)}

Japanese name: Gomafu-nina

(Pl. II, fig. 18)

This species usually gives off elongate oval pellets with one end more or less pointed but the other end rounded. They are well-consolidated and stiff in consistency, fine and homogeneous in surface-texture and uniformly colored yellowish brown. Usually the pellets are composed of well-digestsd algal matters and unidentified micro-organisms. The proportion of length to diameter of the pellets is 3.48 on an average.

Measurement;-

Size of animal $(\mathrm{cm})$

Diam. of pellet $(\mathrm{mm})$

Length of pellet $(\mathrm{mm})$

Length/diam.
$1.3 \times 0.8$ (Spec. No. 102)

$\begin{array}{llllllllllll}0.27 & 0.29 & 0.31 & 0.31 & 0.33 & 0.33 & 0.27 & 0.26 & 0.31 & 0.24 & 0.33 & 0.29\end{array}$

$\begin{array}{lllllllllllll}1.18 & 0.98 & 0.95 & 1.04 & 1.09 & 1.04 & 0.98 & 0.86 & 1.07 & 0.97 & 1.04 & 1.02\end{array}$

$\begin{array}{llllllllllll}4.37 & 3.38 & 3.06 & 3.35 & 3.30 & 3.15 & 3.63 & 3.31 & 3.45 & 4.04 & 3.15 & 3.52\end{array}$

15. Cerithidea (Cerithidea) rhizophorarum ADAMs, 1855

Japanese name: Futo-henatari

(P1. II, fig. 19)

The voided pellets assume the form of a markedly elongated ellipsoid, rounded at one end but tapered to a pointed end at the other. However, they may frequently be oval in outline. The surface of pellets is rather coarse, but smooth and unsculptured. They are dark grayish yellow in color and sometimes patched by darker hue of partially digested algal matters. They are made up of detrital matters including coarse algal fragments and sand grains. The average ratio of length to diameter of the faeces is 8.44 for an animal with a shell $4.7 \mathrm{~cm}$ in height. 
Remarks; In my previous paper of 1963, I described oval pellets of this species with rounded ends. But re-examination of further samples has revealed that the pellets previously described were rather of atypical shape.

Measurements;--

Size of animal $(\mathrm{cm})$

Diam. of pellet $(\mathrm{mm})$

Length of pellet $(\mathrm{mm})$

Length/diam.

$\begin{array}{ccc}0.35 & 0.35 & 0.35 \\ 3.00 & 2.91 & 0.81 \\ 8.57 & 8.31 & -\end{array}$

16. Batillaria zonalis (BRUGUIÈRE, 1792)

Japanese name: Ibo-umi-nina

(Pl. II, fig. 20)

This species voids elongate ellipsoidal pellets. One end of the pellet is rounded as usual, while the other end is tapered to a pointed tip. They are smoothly surfaced, fine and homogeneous in texture, well-consolidated in consistency and yellowish brown in color. They consist of fine well-digested materials probably of an algal origin and contain some diatom frustules and other micro-organisms. The ratio of length to diameter of pellets is 6.40 on an average.

$\begin{array}{lllll}\text { Measurement; - } & & & & \\ \text { Size of animal }(\mathrm{cm}) & & 2.9 \times 1.2 \text { (Spec. No. } 98) \\ \text { Diam. of pellet }(\mathrm{mm}) & 0.40 & 0.33 & 0.33 & 0.38 \\ \text { Length of pellet }(\mathrm{mm}) & 2.26 & 2.18 & 2.49 & 2.20 \\ \text { Length/diam. } & 5.65 & 6.61 & 7.55 & 5.79\end{array}$

\section{Clypeomorus humilis (DUNKER, 1861)}

Japanese name: Kayanomi-kanimori

(P1. II, fig. 22)

The faeces of this species assume an elongated ellipsoid with one end sharply pointed and the other rounded, though occasionally both ends may be rounded. They are usually well-consolidated in consistency, fine and homogeneous in texture and uniformly light grayish brown in color. They are formed mostly of fine detrital matters and some diatom tests, spicules and other unidentified particles. The proportion of length to diameter of the pellets is 4.51 on an average. 
Measurements ;-

Size of animal $(\mathrm{cm})$

$2.1 \times 1.0$ (Spec. No. 100)

Diam. of pellet $(\mathrm{mm})$

$\begin{array}{lllllll}0.27 & 0.27 & 0.26 & 0.26 & 0.31 & 0.29 & 0.26\end{array}$

$\begin{array}{lllllllll}\text { Length of pellet }(\mathrm{mm}) & 1.24 & 1.17 & 1.27 & 1.31 & 1.24 & 1.18 & 1.22\end{array}$

Length/diam.

$\begin{array}{llllllll}4.59 & 4.33 & 4.88 & 5.04 & 4.00 & 4.07 & 4.69\end{array}$

\section{Australaba picta (ADAMS, 1861)}

Japanese name: Shima-hamatsubo

(P1. II, fig. 21)

Pellets of this species are elongate oval or cigar-shaped, with both ends rounded, or frequently obtusely pointed at one end and rounded at the other. Such variations are found even in the pellets voided by the same animal within a short time. The color of pellets varies from light green to dark chocolate green, sometimes spirally striped with a darker hue. The pellets are loosely packed mostly with partially digested algal fragments and some diatom frustules and other micro-organisms. The mean ratio of length to diameter of pellets in some examined animals is 3.55 .

Measurements ;-

Size of animal $(\mathbf{c m})$

$0.65-0.80$ in height (Spec. No. 83)

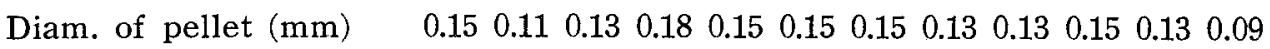

$\begin{array}{llllllllllllllll}\text { Length of pellet }(\mathrm{mm}) & 0.44 & 0.51 & 0.42 & 0.64 & 0.53 & 0.53 & 0.47 & 0.35 & 0.46 & 0.49 & 0.64 & 0.33\end{array}$

Length/diam.

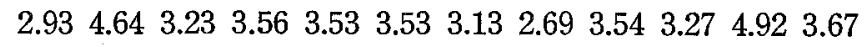

19. Sabia conica (Schumacher, 1817)

Japanese name: Kiku-suzume

(Pl. II, fig. 23, Text-fig. 1)

The pellets are oval in shape and may have a small boss at one end. They are stiff and well-consolidated in consistency, fine and homogeneous in surface-texture, and light greenish gray in color. The average proportion of length to diameter of pellets is 1.69 .

Remarks; This epizoic snail is noted for its coprophagous habit usually feeding on excrements shed by host mollusc. The animal here examined was found adhered on the shell of Euplica scripta, but it was not successful to prove the definite food relationship between the examined sample and the host. 


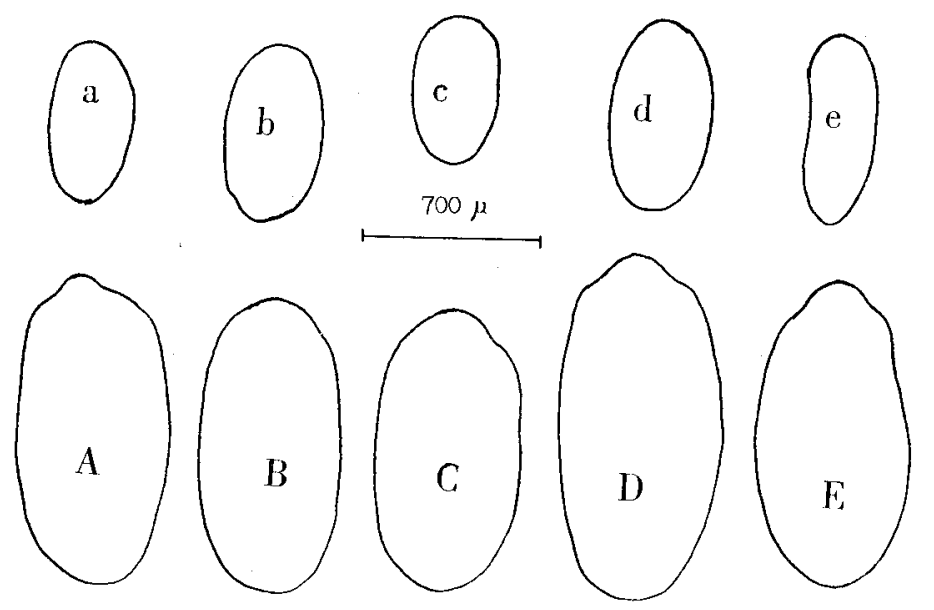

Text-fig. 1. Faecal pellets of Sabia conica voided by the animals reared apart from the host, Turbo cornutus, for thirty days; originally drawn dy Mr. N. MATSUNAGA by using camera lucida. a-e. Faeces shed by males with 5-7 mm shell-length.

A-E. Faeces shed by females with $18-20 \mathrm{~mm}$ shell-length.

20. ?Ravitrona caputserpentis reticulum (LINNÉ, 1758)

Japanese name: Hana-maru-yuki

(P1. III, figs. 24-25, Text-fig. 2)

The faecal rods of this species are of a soft and loose consistency and have sections of indefinite shape. They are formed of a large amount of mucous substance containing some unidentified materials, presumably of an animal origin. The dorsal part of the pellet is rather closely packed with fine well-digested materials, while the axial and ventral parts are sparsely scattered with partially digested coarser matters and a large amount of viscous substance. The rods are light brown in color and their diameter in an examined animal fluctuates from $0.36 \mathrm{~mm}$ to $0.55 \mathrm{~mm}$.

Remarks; In one of the examined pellts, there were found some liberated teeth of a molluscan radula appearantly of the taenioglossate type. Possibly they belong to a certain cypreid in having a rather broad rhachidian with three obtusely pointed cusps, somewhat pectinated plate-like laterals and narrow and hooked uncini with two small toothelts (Text-fig. 2).

21. Tonna luteostoma (KÜSTER, 1857)

Japanese-name : Yatsushiro-gai

(Pl. III, fig. 26) 
Pellets of this species are greatly variable in shape, but mostly they are oblong ovate or elongate ellipsoidal in outline; occasionally, however, they may be twisted or rarely united together in a string. These pellets are usually enclosed each within a thin membranous capsule and uniformly colored dark brown. They are composed of well-digested materials, probably of an animal origin. The pellet-diameter ranges from $0.4 \mathrm{~mm}$ to $1.0 \mathrm{~mm}$.

\section{Rapana thomasiana (CROSSE, 1861)}

\section{Japanese name: Aka-nishi}

(P1. III, figs. 27-28)

The pellets of this species consist of thin rod-like constituents closely compacted by a modicum of mucus into a much thicker rod with an oval section. They are uniformly grayish brown in color when preserved in formalin. They are made of well-digested materials of an animal origin. For an examined animal, rods are $5.0 \mathrm{~mm}$ in average diameter, while the constituent rodlets are $1.5 \mathrm{~mm}$ thick across.

\section{Ocenebra japonica (DUNKER, 1860) \\ Japanese name : Ô-yôraku \\ (Pl. III, fig. 29)}

The faecal rods of this species are cylindrical, but usually shed broken in shorter pieces of the length approximately five times as large as the diameter. The surface of pellets is smooth and unsculptured, except for transverse cleft occasionally formed. They are grayish green in color, rather fine in texture and formed mostly of fine materials. The pellet-diameter fluctuates from $0.15 \mathrm{~mm}$ to $0.24 \mathrm{~mm}$ for an animal with a shell $3.5 \mathrm{~cm}$ in height.

\section{Euplica scripta (LAMARCK, 1822)}

Japanese name: Futokoro-gai

(P1. III, figs. 30-32)

The faecal pellets are made of unidentified fine matters mingled with a large amount of viscous substance, and assume a rod with a roughly oval section. They are soft and fragile in consistency and light yellowish brown in color. The surface is not smooth, but rather rough in texture, being marked by random cracks. The gross diameter of faeces voided by an animal with a shell $1.6 \mathrm{~cm}$ long is $0.87 \mathrm{~mm}$. 


\section{Haloa japonica (PILSBRY, 1895)}

Japanese name: Budô-gai

(P1. III, fig. 33)

Faecal rods are cylindrical and consist of rather coarse costituent materials loosely packed. The surface of pellets is uneven and very rough, and carrying a considerable amount of mucus. The pellets are formed of fine detrital matters mixed with coarse algal fragments. The diameter of the pellets voided by an animal with a $1.1 \mathrm{~cm}$ long shell fluctuates in the range $0.68-0.73 \mathrm{~mm}$.

26. Lymnaea (Radix) japonica JAY, 1857

Japanese name: Mono-ara-gai

(P1. III, figs. 34-35)

The faeces are roughly cylindrical and rod-shaped, marked with a single shallow longitudinal groove which is presumably printed by the typhlosole on passing through the alimentary canal. Rods are usually fairly long attaining the length six to eight times the diameter. They are yellowish brown in color, occasionally variegated with chocolate or dark green hue, and made almost of detrital matters containing some large partially digested materials. The diameter of the pellets shed by an animal with a shell $1.1 \mathrm{~cm}$ in length is $0.51 \mathrm{~m}$.

\section{Achatina (Lissachatina) fulica (BowDIcH, 1822)}

Japanese name: Africa-maimai

(P1. IV, figs. 36-37; Text-fig. 3)

This species voids thick cylindrical rods with a diameter $2.5 \mathrm{~mm}-4.5 \mathrm{~mm}$. They contain usually two kinds of constituent filaments derived from the liver string. One of these filaments is thin, deep green in color, consists solely of finer material and is running through the rod straightly in regular double coiling, while the other is thicker than the former, yellowish green in color and made of somewhat coarser material. The former can be liberated rather easily in a perfect state from the rest of the faecal rod (derived from the stomach string) by dissection with needles. In general, the color of pellets is yellowish white. They are composed mostly of rather coarse matters, probably of a vegetal origin and usually accompanied with a large amount of mucus. 


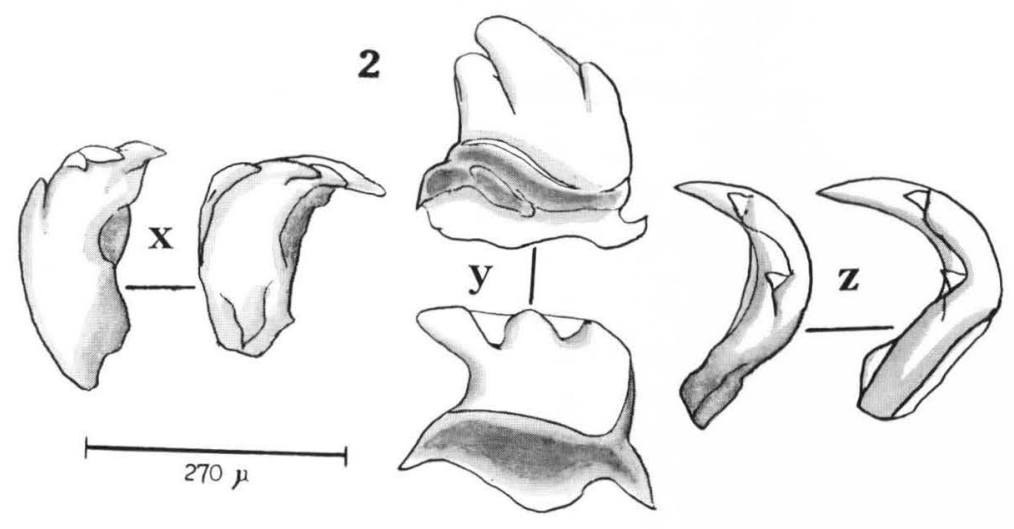

Text-fig. 2. Radular teeth of some cypreid found in a pellet of Ravitrona caputserpentis reticulum. $\mathrm{x}$. laterals $\mathrm{y}$. rhachidian $z$. uncini

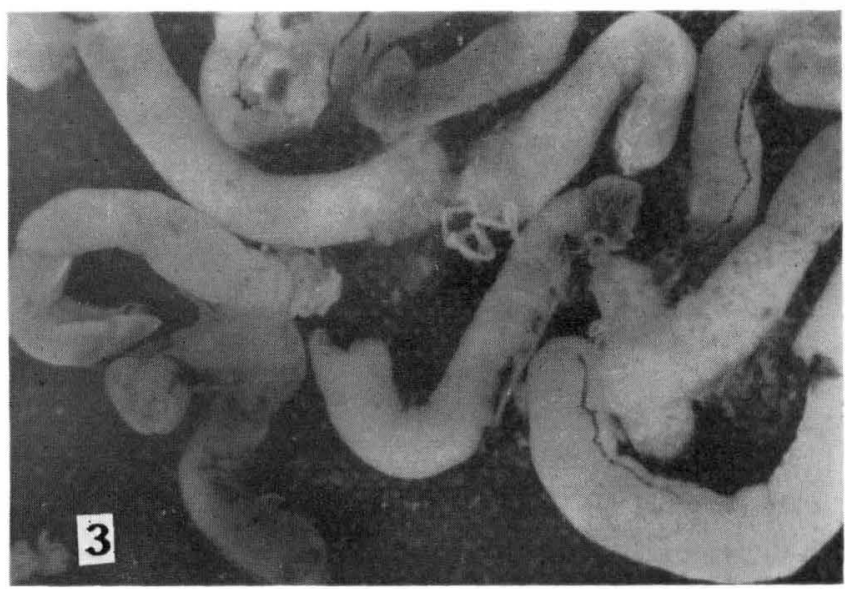

Text-fig. 3. Faecal pellets of Achatina fulica.

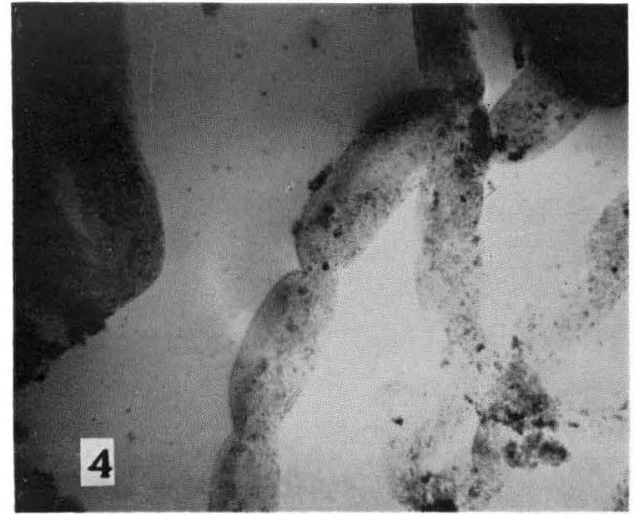

Text-fig. 4. Faecal pellets of ? Aplysia kurodai.

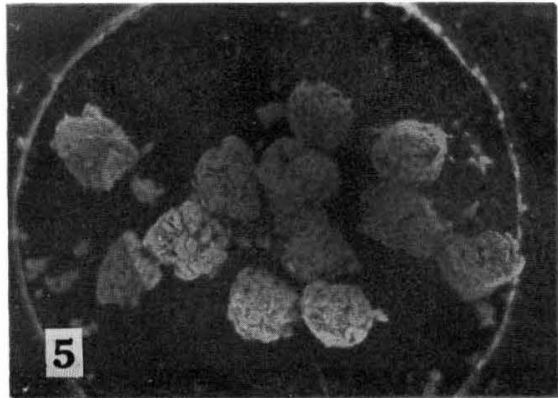

Text-fig. 5. Faecal pellets of Pecten albicans (photographed by Dr. S. OTA of the National Pearl Research Laboratory). 
28. Bradybaena similaris (FÉRUSSAC, 1822)

Japanese name: Onaji-maimai

(Pl. IV, fig. 38)

The pellets assume a cylindric rod with a very coarse texture. They are yellowish green in color and composed almost of undigested coarse fragments of a vegetal origin. For an animal with a shell $0.95 \mathrm{~cm}$ high and $1.60 \mathrm{~cm}$ wide, the diameter of pellets varies from $0.78 \mathrm{~mm}$ to $1.18 \mathrm{~mm}$.

\section{Limax sp.}

(Pl. IV, fig. 39)

Pellets of this species are very variable in shape; they are usually elongate oval, but frequently some are joined together in a string, or occasionally they may be flocculent. The color ranges from dark gray to black and the surface-texture is rather fine. Pellets are usually accompanied with a modicum of mucus.

\section{0. ?Aplysia (Virria) kurodai (BABA, 1937) \\ Japanese name: Amefurashi}

(Text-fig. 4)

Faeces of this species are rod-shaped and regularly constricted at intervals of nearly 2.5 times as long as the diameter. They are somewhat translucent and light grayish green in color, and consist almost of a large amount of jelly-like substance containing partially digested algal fragments, diatoms and unidentified minute particles. For an examined animal, the diameter of pellets is $0.38 \mathrm{~mm}$ on an average.

\section{Anadara (Scapharca) subcrenata (LIScHKE, 1869) \\ Japanese name: Saru-bô \\ (Pl. IV, fig. 41)}

The faecal pellets of this species are ribbon-shaped, without any external sculptures, and usually shed broken to short pieces. Both lateral edges of the pellet are thickened and slightly turn dorsads, while the central area is much thinner and the dorsal side is moderately concave; thus the general appearance of faeces assumes a form of gutter. They are light yellowish brown in color, rather coarse in texture and soft and very frail in consistency. 
The faeces are made of rather fine materials mixed with diatom frustules and some unidentified larger particles. For an examined animal, the width of ribbons fluctuates in the range $0.73 \mathrm{~mm}-1.09 \mathrm{~mm}$.

\section{Barbatia (Savignyarca) virescens obtusoides (NYST, 1848)}

Japanese name: Karigane-e-gai

(Pl. IV, figs. 40, 46)

The pellets are ribbon-shaped, about $0.73 \mathrm{~mm}$ in width. There are no prominent surface sculptures, but five or six obscure longitudinal striae on each side. They are soft and fragile in consistency and somewhat coarse in texture. The pellets are loosely packed with fairly coarse materials.

\section{Septifer bilocularis pilosus (REEve, 1843)}

Japanese name: Mino-kujaku

(Pl. IV, fig. 42)

The present species gives off ribbon-shaped pellets with a bi-crescentic section. The dorso-median ridge is small but rather conspicuous. On the contrary, there is a shallow but wide mid-ventral groove on the opposite side. They are grayish brown in color, coarse in texture and usually made of somewhat coarse materials. For an animal with shells $2.4 \mathrm{~cm}$ long, the width of ribbons is $0.36 \mathrm{~mm}$.

\section{Amusium japonicum (GMELIN, 1791)}

Japanese name: Tsukihi-gai

$$
\text { (Pl. IV, fig. 43) }
$$

Faeces of this species are composed of filamentous cylindric rods loosely entangled and gathered by mucus to form masses of indefinite shapes, although it is assumed that the normal faeces are formed much more tightly in the shape of a ball of the size variable with individuals. They are soft and fragile in consistency, usually carrying a large amount of mucus, and colored brownish orange to brownish green; the pellet-texture is fine and homogeneous in brownish orange pellets, while it is rather coarse in brownish green ones. They are made of detrital matters containing numerous unidentified micro-organisms and some small particles. The diameter of rods fluctuates from $0.07 \mathrm{~mm}$ to $0.08 \mathrm{~mm}$, for an examined animal. 


\section{Pecten (Notovola) albicans (ScHRÖTER, 1802)}

\section{Japanese name: Itaya-gai}

(P1. IV, fig. 44, Text-fig. 5)

As in the preceding species, pellets of this species are made of filamentous rods entangled and compacted into a ball by a large amount of mucous substance. The balls thus formed by the same animal within a short time vary greatly in size and shape. For an animal with shells $7.7 \mathrm{~cm}$ long, the diameter of faecal balls fluctuates in the range $1.8 \mathrm{~mm}-2.1 \mathrm{~mm}$ and that of constituent rods $0.15-0.20 \mathrm{~mm}$.

Remarks; The general appearance of faecal balls of the present species agree very closely to that of Pecten maximus (LINNE) described by Moore (1932).

\section{Lima sowerbyi Deshayes, 1863}

Japanese name: Mino-gai

(Pl. IV, fig. 45)

In this species, thin thread-like constituent rods are compacted into cylindrical rods, usually voided in pieces of the length three to four times as long as the diameter. They are formed almost of detrital matters mingled with some diatom frustules. The pellet-diameter fluctuates from $0.42 \mathrm{~mm}$ to $0.44 \mathrm{~mm}$.

37. Crassostrea gigas (THUMBERG, 1793)

Japanese name: Ma-gaki

(Pl. V, figs. 48-50, Pl. VI, figs. 1-5)

At first sight, this species appears to void typical rod-shaped pellets, but closer examination of cross sections of pellets shows that they are rather of a modified ribbon type. The ventral side of pellets is smoothly surfaced and unsculptured, while the dorsal side is marked by two deep longitudinal grooves embracing a low narrow longitudinal ridge in between them. This structure is, however, easily overlooked, as it is wholly covered by welldeveloped lateral wings of the ribbon. Both edges of the ribbon upcurled over the dorsal side may touch each other and thus the real dorsal side of the pellet is entirely concealed. The pellets are rather stiff in consistency, voided usually in short pieces, and colored orangy yellow. They are made of undetermined well-digested materials mixed with numerous diatom frustules and other skeletal matters. In section, there is found a concentration 
of coarser materials towards the centre. The average diameter of pellets shed by an examined animal is $0.78 \mathrm{~mm}$.

Remarks; Anatomical examination of the alimentary canal of this species demonstrates clearly that the shape of the faecal pellet is determined by the internal structure of the canal.

In Pl. VI, fig. 1, is shown a cross section of the alimentary canal of well-fed animal. Here the canal is expanded and roughly rounded in outline, and two prominent typhlosoles applying to two deep longitudinal grooves on the dorsal side of the pellet are shown distinctly. Then, a cross section of the canal of a starved animal is shown in fig. 2 ; now the canal is much more flattened and shows the structure to yield thin ribbon-shaped faeces. Finally in fig. 3, a section of the canal of the animal infected by some parasitic worms is given; the ventral structure of the canal is deformed and the lumen is narrowed to produce only flocculent faeces of indefinite shape.

Further, a cross section of the gut of Ostrea denselamellosa is presented in fig. 6 ; this structure is supposed to yield flattened ribbon-shaped pellets with a bi-crescentic section.

\section{Saxostrea echinata (Quoy et GAIMARD, 1835)}

Japanese name: Ke-gaki

(P1. V, fig. 47)

Pellets of the present species are ribbon-shaped, and carry a modicum of mucus. Both lateral edges of the ribbon is thickened and slightly turn dorsads, and the dorsal side is fairly raised along the median line to form a low dorso-median ridge, while the opposite ventral side is flattened and unsculptured. Pellets are coarse in texture, soft and friable in consistency and dark green in color. They are formed of rather coarse materials containing numerous larval shells of some lamellibranch. For an animal with shell $5.8 \mathrm{~cm}$ long and $2.0 \mathrm{~cm}$ wide, ribbons are $1.27 \mathrm{~mm}$ in width on anerage.

\section{Scintilla japonica (ADAMS, 1862)}

\section{Japanese name: Mame-agemaki-gai}

This species gives off ovoid pellets with twelve or thirteen constrictions, or sometimes without any surface-sculpturings. The pellets are dark brownish green in color, fine and homogeneos in texture, and mostly composed of fine detritus containing unidentified micro-organisms, algal fragments and some diatom frustules (Navicula, Rhizosolenia, Coscinodiscus etc). The average proportion of length to diameter of pellets shed by an animal with shells $1.3 \mathrm{~cm}$ long and $0.65 \mathrm{~cm}$ high is 1.68 , 
Remarks; The description of pellets of this scintilloid mollusc was ever given by me together with illustrations (1962, p. 64) under the name of Scintilla vitrea QuOY et GAIMARD, 1832 with which the mollusc has been identified by Japanese malacologists. Recently, however, Dr. Tokubei Kuroda kindly informed me that mollusc should be identified with $S$. japonica (Adams, 1862), and thus the re-description of pellets are given here under the correct name.

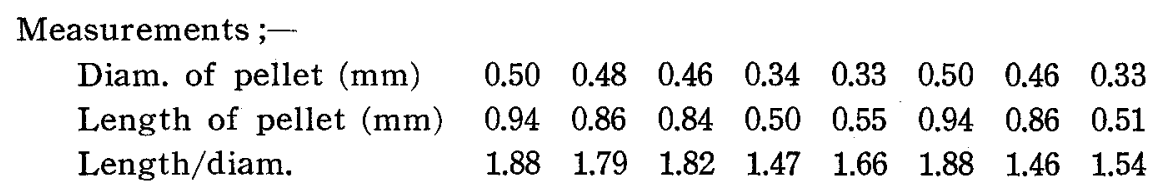

\section{Fulvia mutica (REEvE, 1844)}

Japanese name: Tori-gai

(P1. V, fig. 51)

Pellets of this species are rod-shaped, deeply constricted at regular intervals of about 1.3 times as long as the diameter and readily broken up into ovoid pieces with truncate end by a slight touch. They are fine, very firm in consistency, colored uniformly grayish green and consist entirely of fine detritus containing some diatom frustules. For an examined animal, the average diameter of pellets in $0.82 \mathrm{~mm}$.

\section{Meretrix lusoria (RöDING, 1798) \\ Japanese name: Hamaguri}

(P1. V, fig. 52)

This species gives off the rods that are cylindrical and marked with a slight longitudinal groove presumedly printed by the typhlosole. Occasionally, the rod contains a single constituent filament spirally coiled (fig. 52, middle), or rarely it may be made mostly of a simple very long constituent filament derived from the liver string folded and compacted to form a rod (fig. 52, below). The diameter of pellets voided by an animal with shells $6.5 \mathrm{~cm}$ long, fluctuates in the range $1.3 \mathrm{~mm}-2.0 \mathrm{~mm}$ and that of constituent filaments is $0.26 \mathrm{~mm}$.

42. Dosinia (Phacosoma) japonica (REeve, 1850)

Japanese name: Kagami-gai

(Pl. V, fig. 53 ; P1. VI, fig. 7)

The faeces are of a tỵpical cylindriçal rod and without any external 
sculptures. They are rather coarse in texture, firm in consistency, dark grayish green in color, and formed of rather fine detrital matters containing some coarse unidentified organisms. The pellet-diameter fluctuates from $0.51 \mathrm{~mm}$ to $0.53 \mathrm{~mm}$, for an animal with shells $4.7 \mathrm{~cm}$ hight.

Remarks; The anatomical examination of the alimentary tract shows that the circular cross section of the tract coincides exactly with the section of the faecal pellet (Pl. 6, fig. 7).

43. Octopus (Octopus) marginatus TAKI, 1964

Japanese name: Mejiro-dako

(P1. V, figs. 54-55)

Faecal rods of the present species are cylindrical with a circular cross section and without any surface sculptures. They are coarse in texture and formed almost of well-digested grayish white materials mixed with numerous small dark red particles densely and homogeneously scattered. The diameter of faeces voided by an examined animal is $0.38 \mathrm{~mm}$ on an average.

\section{Octopus (Octopus) minor variabilis (SASAKI, 1929)}

\section{Japanese name: Tenaga-dako}

$$
\text { (Pl. V, fig. 56) }
$$

This octopus sheds the compact pellets which are made of thread-like constituents, or occasionally thick rod-shaped pellets smoothly surfaced. They are soft in consistency and composed of well-digested matters, probably of an animal origin. The color of pellets varies greatly, from grayish whiteyellow to purplish brown according to the staple food taken by the animal. The pellet-diameter ranges from $0.55 \mathrm{~mm}$ to $1.18 \mathrm{~mm}$ for an examined animal.

\section{BIBLIOGRAPHY}

For other references, see ARAKAwA (1962).

ARAKAWA, K. Y. (1962): A coprological study on the molluscan faeces (A preliminary note). Jap. Jour. Malac., XXII (2), 151-172. $185-208$

CARRIKER, M. R. (1946): Observations on the functioning of the alimentary system of the snail Lymnaea stagnalis appressa SAY. Biol. Bull., 91, 88-111.

EDGE, E. R. (1934): Faecal pellets of some marine invertebrates. Amer. Midl. Nat., 15 (1), $78-84$.

Fretter, V. \& A. CRAham (1962): British prosobranch mollusca. Ray society. London. Frost, S. W. (1928): Insect scatology. Annals Entom. Soc. Amer. XXI, 36-46.

Matsunaga, N. (1964): Remarks on the ecological observation of a Japanese hoof shell, Hipponix (Sabia) conicus (SchüMAcher). Jap. Jour. Malac., XXIII (3), 149-158, 


\section{EXPLANATION OF PLATES I-VI.}

Pl. I. Faecal pellets of:

1. Ischnochiton comptus

2. Nordotis discus

8. Trochus sacellum rota

3. $\quad$ (cross-section)

4. Montfortula pulchra

(dorsal side)

9. $\quad$ (ventral side)

10. " (cross-section)

5. Cellana nigrolineata

6. Notoacmea fuscoviridis

11. Turbo cornutus

7. Calliostoma unicum

12. $\quad$ (cross-section)

Pl. II. Faecal pellets of :

13. Lunella coronata coreensis

18. Planaxis sulcatus (dorsal side)

14. " (lateral side)

19. Cerithidea rhizophorarum

15. " (ventral side)

20. Batillaria zonalis

16. Cipangopaludina malleata

21. Australaba picta

17. Serpulorbis imbricatus

22. Clypeomorus humilis

23. Sabia conica

P1. III. Faecal pellets of :
24. Ravitrona caputserpentis reticulum
30. Euplica scripta (dorsal side) (lateral side) 31 (lateral side)
25. (dorsal view)
26. Tonna luteostoma
32. " (cross-section)
33. Haloa japonica
27. Rapana thomasiana
28. " (constituent pellet)
29. Ocenebra japonica
34. Lymnaea japonica
35. (cross-section)

Pl. IV. Faecal pellets of :

36. Achatina fulica

37. " (constituent filament)

38. Bradybaena similaris

39. Limax sp.

40. Barbatia virescens obtusoides

41. Anadara subcrenata

P1. V. Faecal pellets of:
47. Sexostrea echinata
48. Crassostrea gigas (ventral side)
49. (dorsal side)
50. (cross-section)
51. Fulvia mutica

52. Meretrix lusoria

53. Dosinia japonica

42. Septifer bilocularis pilosus

43. Amusium japonicum

44. Pecten albicans

45. Lima sowerbyi

46. Barbatia virescens obtusoides

54. Octopus marginatus

55. " (cross-section)

56. $\quad$ O. $\quad$ minor variabilis 
P1. VI. Cross-sections of the alimentary tract of some pelecypods examined. (All photographs are of the slide preparations preserved in the laboratory of Dr. Y. Ogasawara, who allowed me so kindly to cite them here; all highly magnified).

1. Section of the gut of Crassostrea gigas (well-fed specimen).

2. " " $\quad$ (starved specimen).

3. " " " (specimen infected by parasitic

worms, p-parasites).

4. A part of the section of the gut of the same species.

5. Food materials packed in the gut of the same species,

6. Section of the gut of Ostrea denselamellosa.

7. Section of the gut of Dosinia japonica. 
Publ. Seto Mar. Biol. Lab., XIII (1), 1965

PLATE I
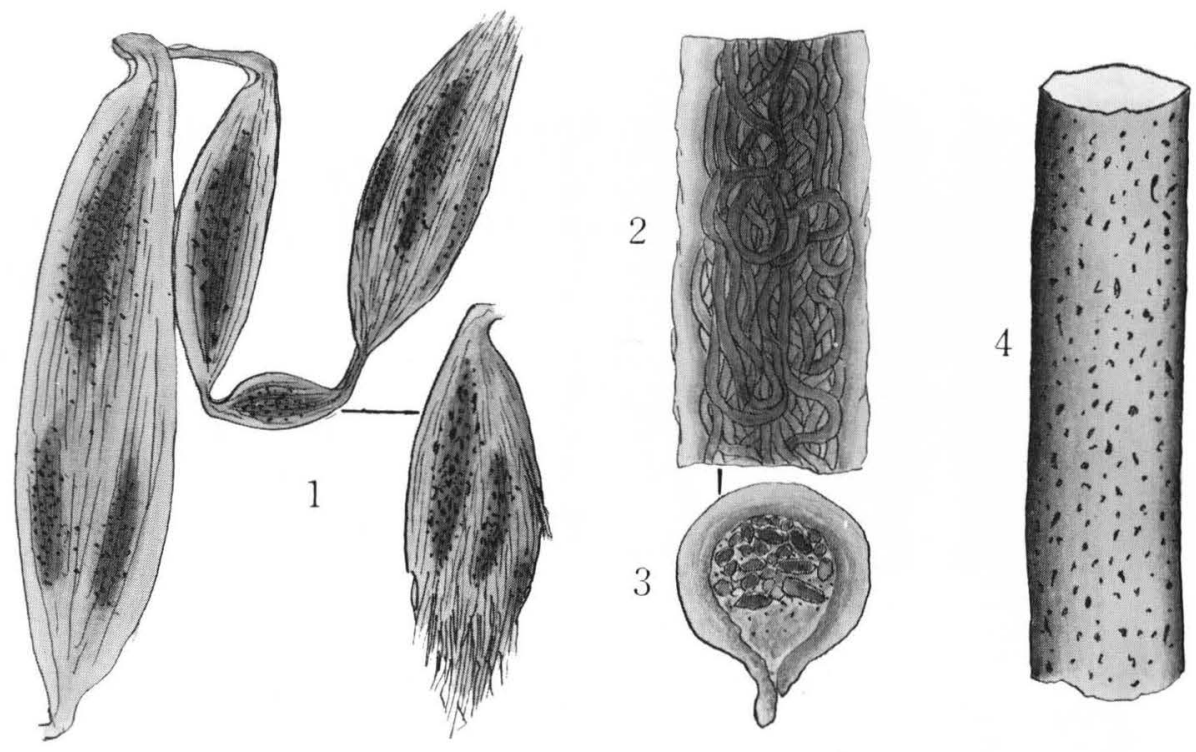

5

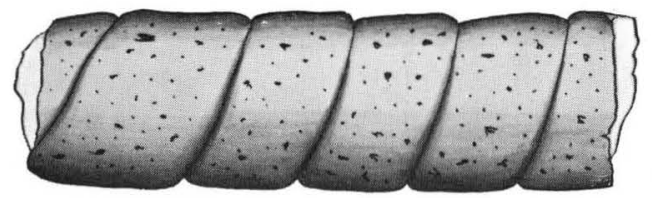

7
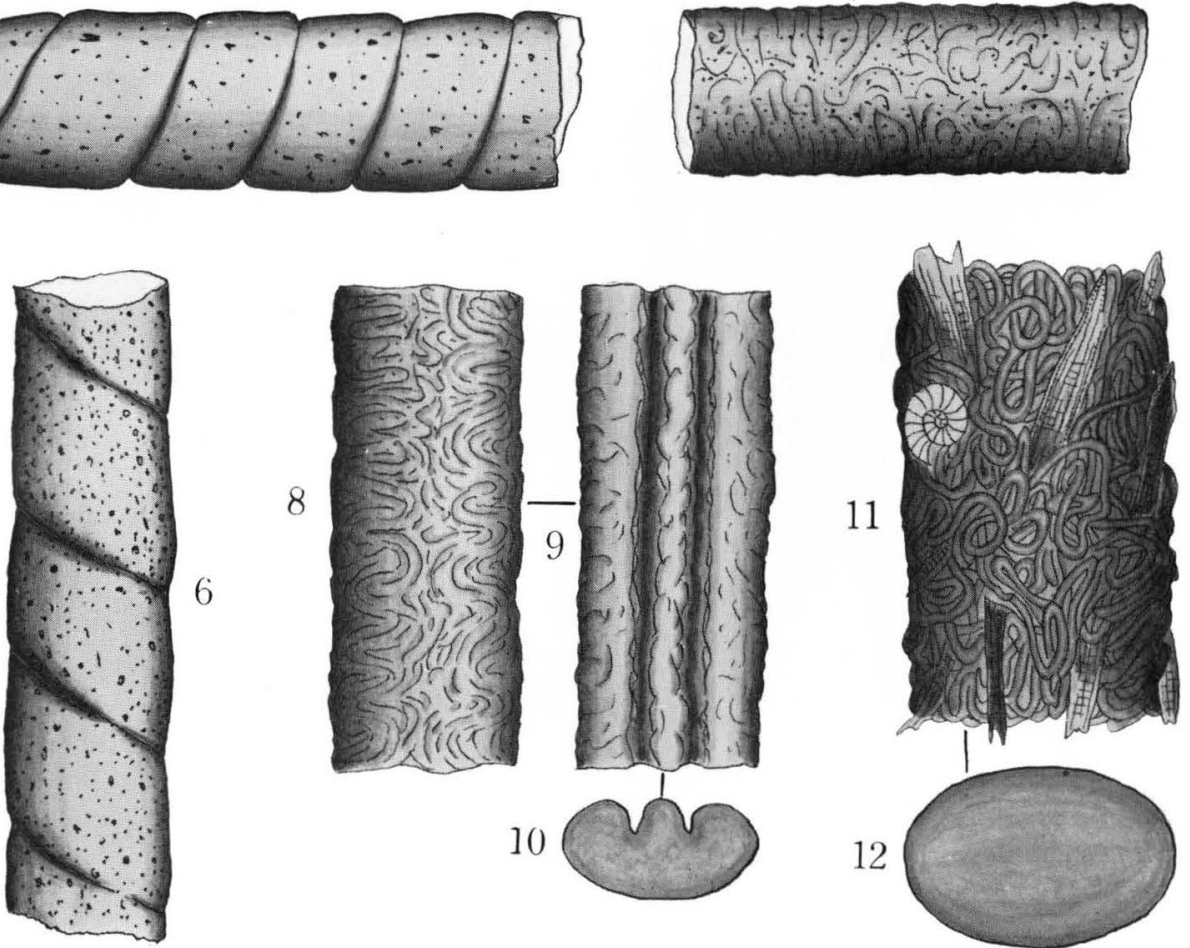

K. Y. Arakawa: Studies on Molluscan Faeces (II). 
Publ. Seto Mar. Biol. Lab., XIII (1), 1965

Plate II

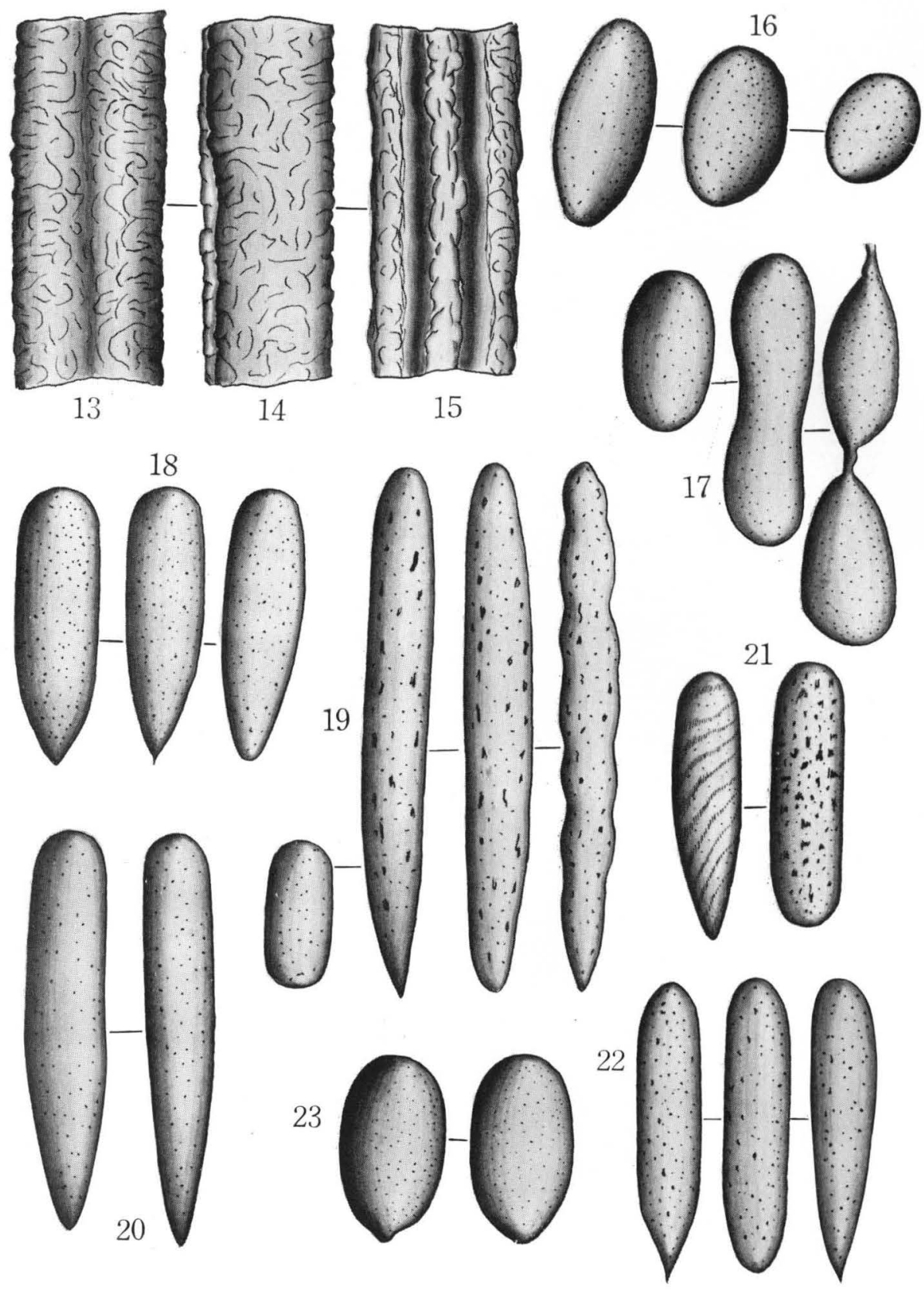

K. Y. Arakawa: Studies on Molluscan Faeces (II). 
Publ. Seto Mar. Biol. Lab., XIII (1), 1965

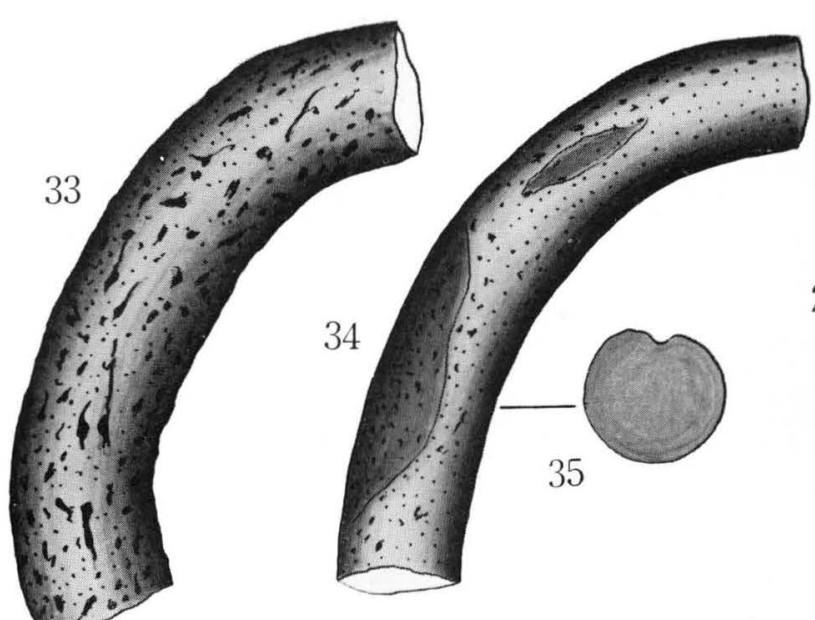

29
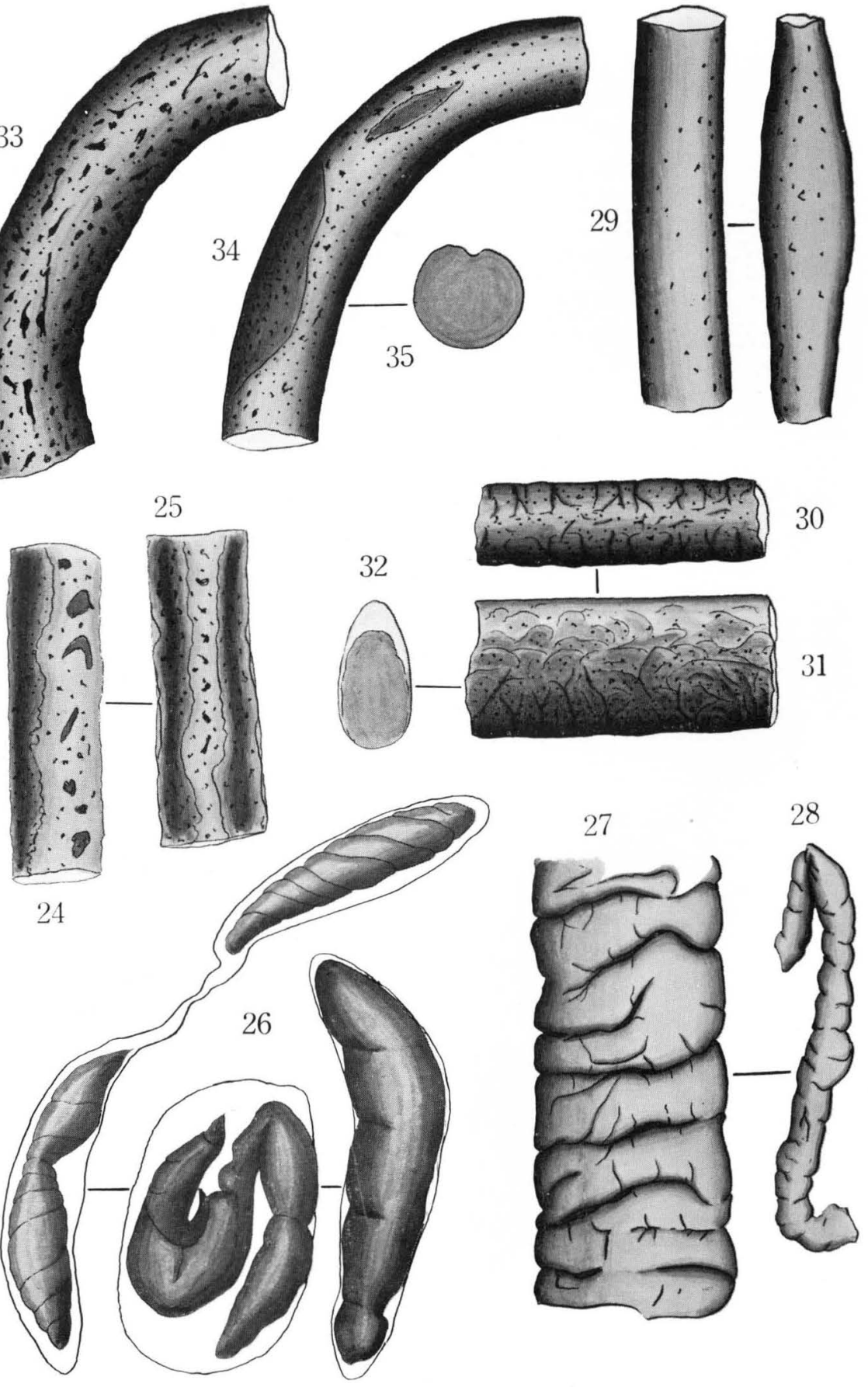

K. Y. Arakawa: Studies on Molluscan Faeces (II). 
Publ. Seto Mar. Biol. Lab., XIII (1), 1965 PLATE IV
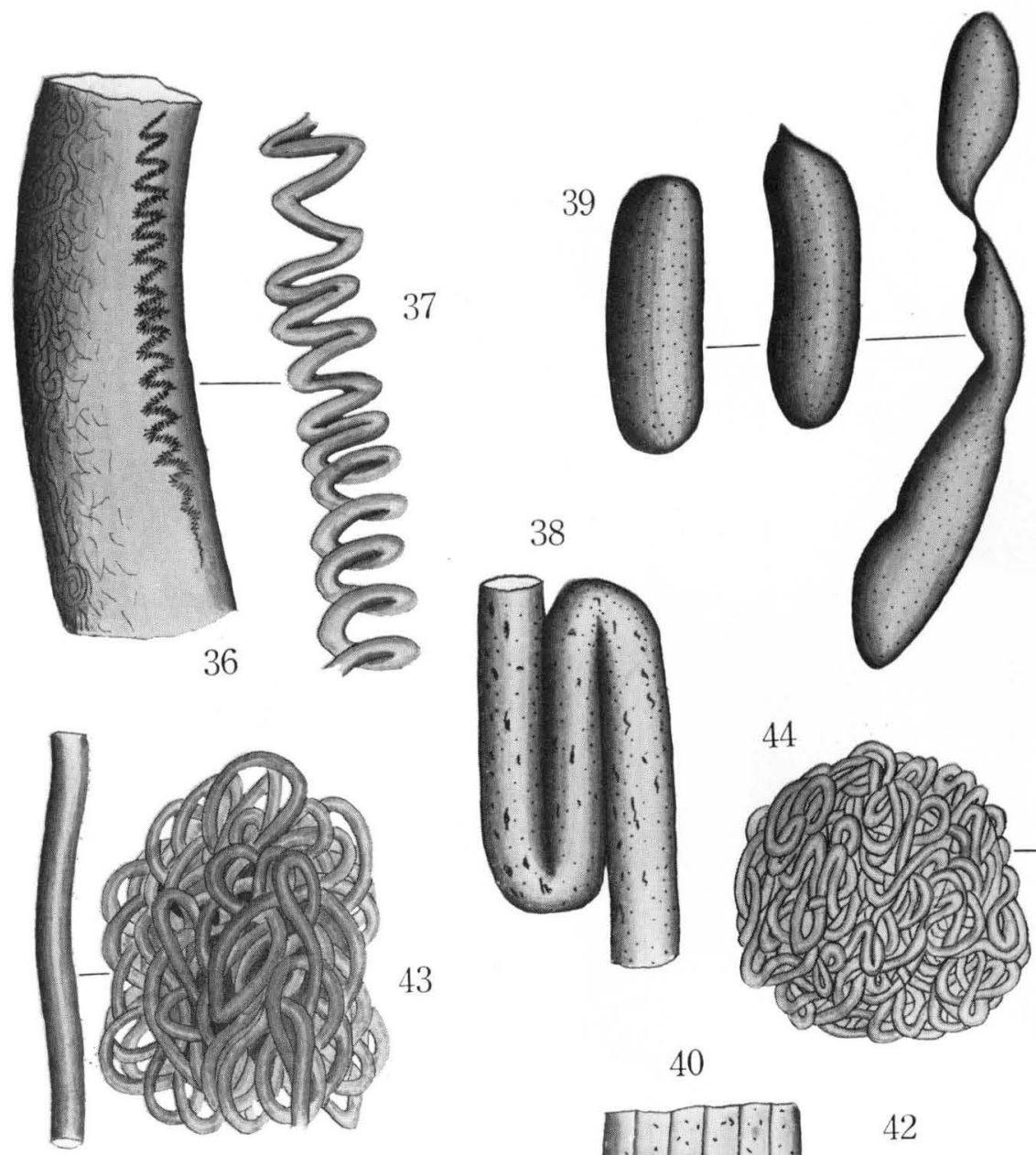

41

45
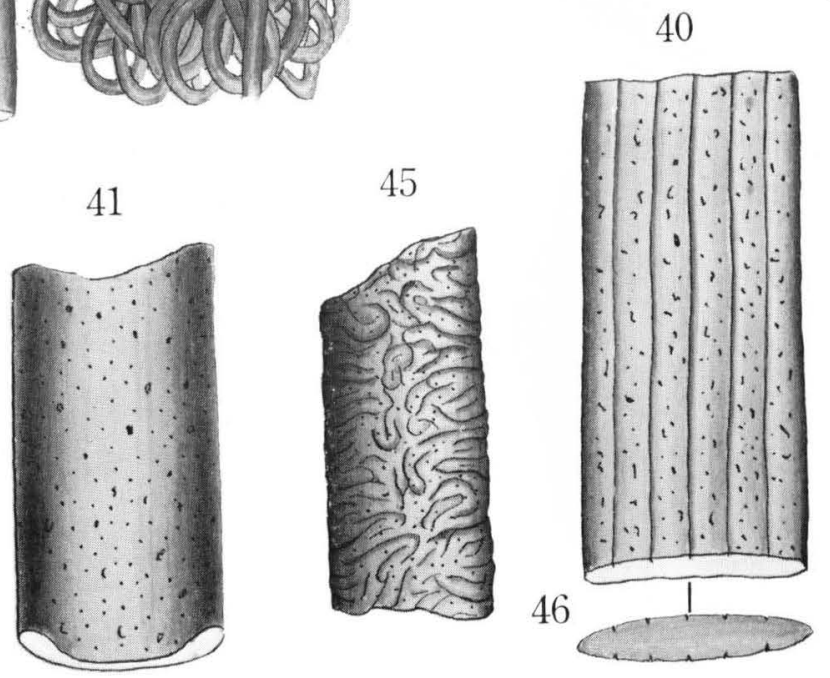

42

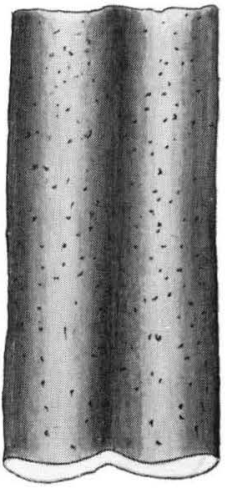

K. Y. Arakawa: Studies on Molluscan Faeces (II). 
Publ. Seto Mar. Biol. Lab., XIII (1), 1965 PLATE V
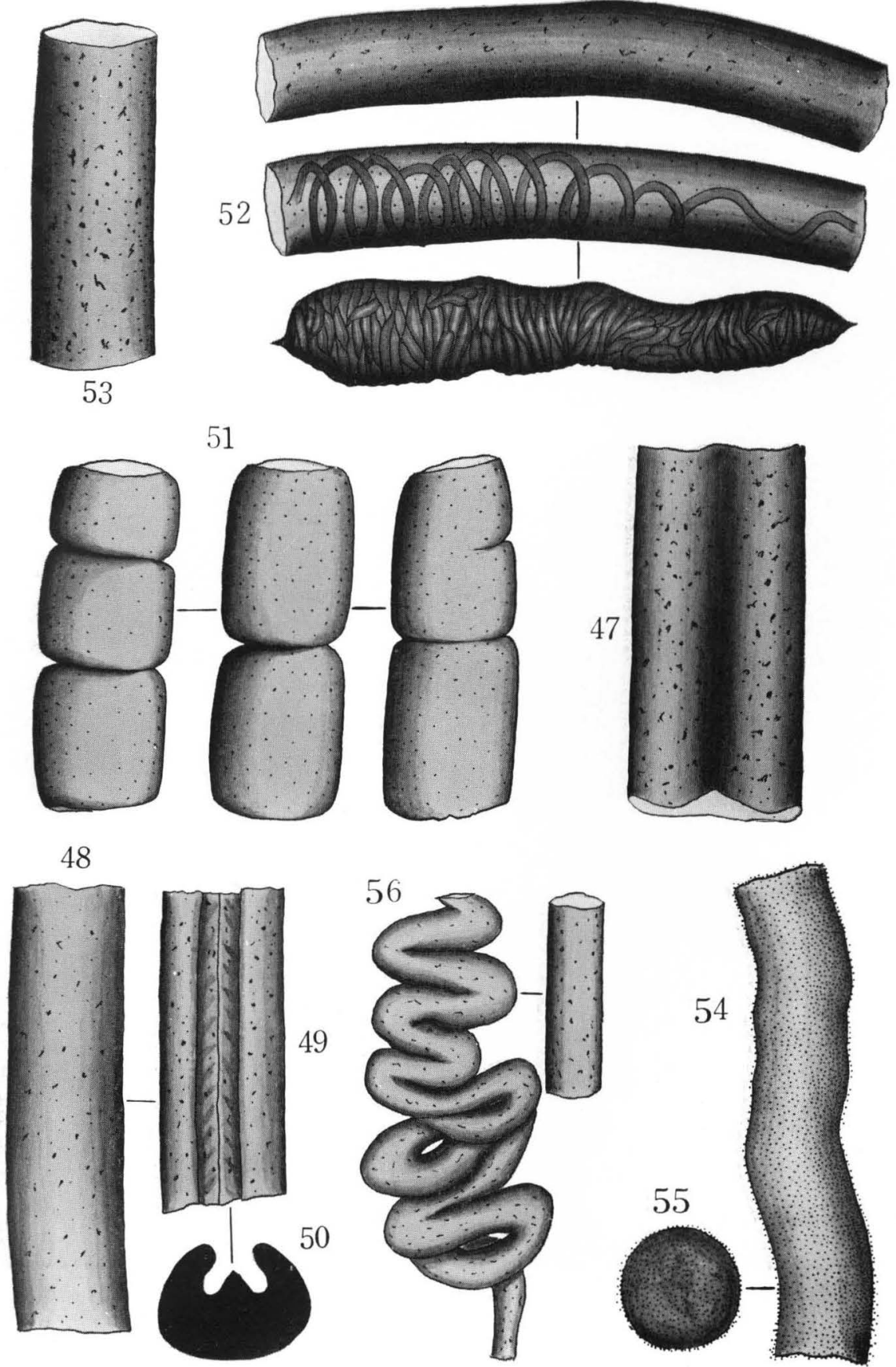

K. Y. Arakawa: Studies on Molluscan Faeces (II). 
Publ. Seto Mar. Biol. Lab., XIII (1), 1965 PLATE VI

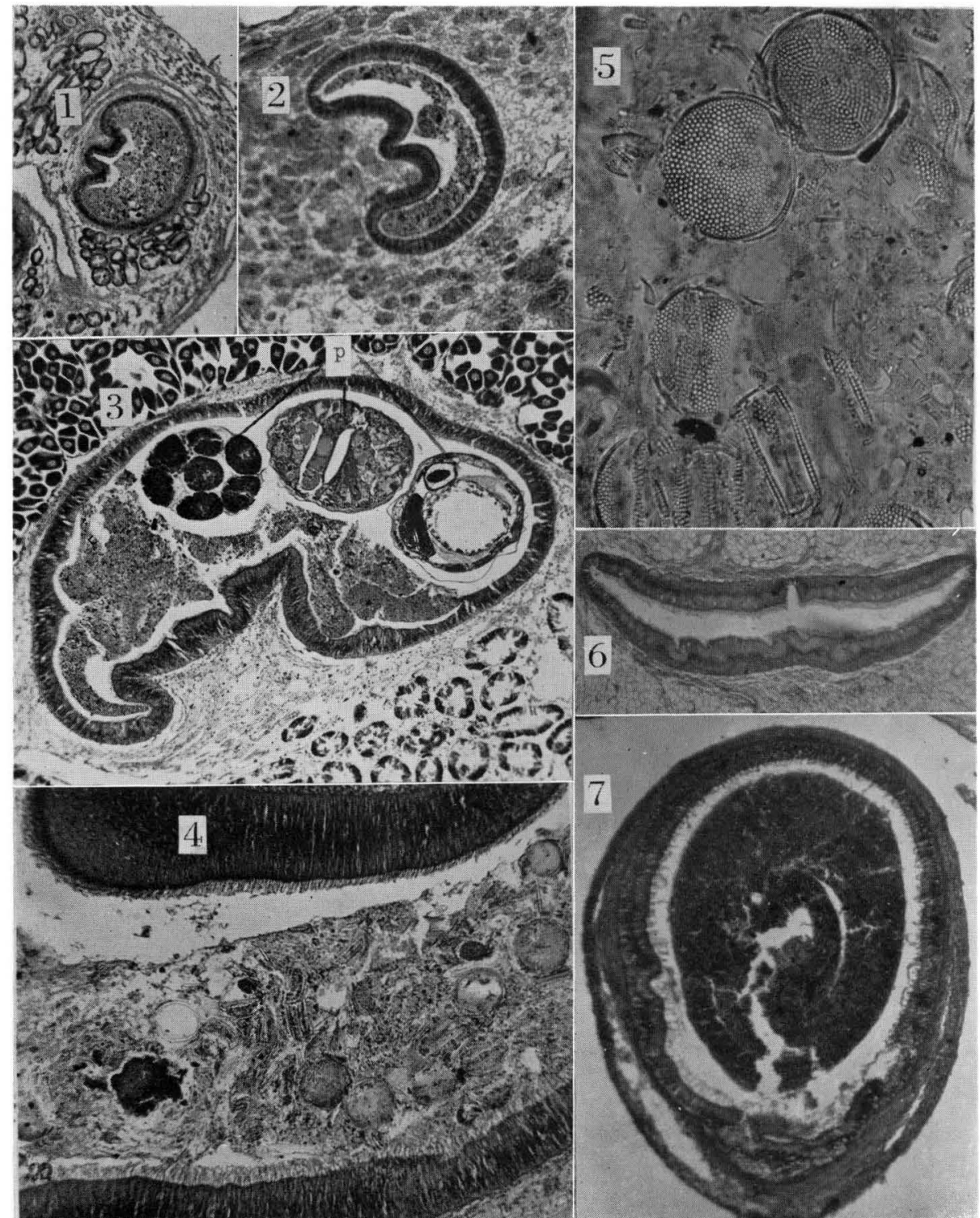

K. Y. Arakawa: Studies on Molluscan Faeces (II). 